\title{
ANALISA KARAKTERISTIK BIODIESEL NYAMPLUNG
}

\author{
Seno Darmanto' ${ }^{1)}$, Windu Sediono ${ }^{1)}$, Sarwoko $^{2)}$, Triyatno ${ }^{1)}$ \\ ${ }^{1)}$ Program Diploma III Teknik Mesin Fakultas Teknik Universitas Diponegoro \\ ${ }^{2)}$ Program Diploma III Teknik Perkapalan Fakultas Teknik Universitas Diponegoro
}

\begin{abstract}
Seno Darmanto, Windu Sediono, Sarwoko, Triyatno, in this paper explain that making of callophylum inophylum biodiesel fuel is done alkaly transesterification methode. Alkaly transesterification methode use methanol and basa $(\mathrm{NaOH})$ of catalist. Procedur and setting of research that is consisted in material selection, treatment and setting of composition of methanol and catalist, operational temperature, reaction time, speed and mixer technical will effect quality and conversion level of callophylum inophylum biodiesel. And based data analyzer show that conversion of callophylum inophylum biodiesel can reach 90\%. Properties of callophylum inophylum biodiesel show viscosity and flash point of callophylum inophylum biodiesel is ligthly higher than diesel fuel. And caloric value of callophylum inophylum biodiesel is slightly lower than diesel fuel.
\end{abstract}

Key words: callophylum inophylum, biodiesel, properties, transesterification.

\section{PENDAHULUAN}

Tanaman nyamplung (callophylum inophylum) mulai mendapat perhatian kembali secara khusus oleh pemerintah dan lembaga swadaya internasional sehubungan dengan permasalahan bahan bakar minyak yang berfluktuasi dan lingkungan (pemanasan global dan kenaikan permukaan air laut). Kebijakan energi biofuel yang bersumber dari minyak nabati non pangan telah mendorong pemerintah dan lembaga internasional untuk segera mengimplementasikan penanaman kembali tanaman penghasil minyak non pangan seperti jarak pagar (jatropha curcas), kapuk randu, nimba, nyamplung, randu alas dan lain-lain (Prakoso, 2005).

Potensi tanaman nyamplung cukup besar namun belum tergarap secara maksimal. Potensi manfaat tanamam nyamplung dapat digali dari batang, getah, biji, bunga dan daun. Batang tanaman nyamplung dapat digunakan untuk bahan pembuatan perahu, balok, tiang, papan lantai, papan pada bangunan perumahan dan bahan konstruksi ringan. Getah yang disadap dari batang nyamplung mengandung minyak dan mempunyai indikasi berkhasiat untuk menekan pertumbuhan virus HIV. Daun nyamplung mengandung senyawa costatolidea, saponin dan acid-acid hydrocyanic yang berkhasiat sebagai obat oles untuk sakit encok, bahan kosmetik untuk perawatan kulit, penyembuhan luka (luka bakar dan luka potong). Biji nyamplung diolah menjadi minyak dan telah dimanfaatkan untuk plitur, minyak rambut, minyak urut, obat urus-urus dan rematik. Bunganya dapat digunakan sebagai campuran untuk mengharumkan minyak rambut. Dengan berbagai potensi keunggulannya, nyampung dapat menjadi tanaman yang memberikan multifungsi dan manfaat meliputi tanaman rehabilitasi hutan dan lahan, alternatif biofuel dan meningkatkan pemberdayaan masyarakat (www.mojokerto.go.id, 2008).

\section{METODE PENELITIAN}

Bahan utama yang digunakan dalam penelitian meliputi minyak nyamplung (callophylum inophylum oil), metanol, dan $\mathrm{NaOH}$. Sedangkan peralatan yang digunakan dalam penelitian meliputi bekker glass, gelas ukur,termometer, pipet mata, labu takar, stirer pemanas dan magnet, statip dan klem, neraca ohaus (digital), stopwacth, pengaduk dan corong pemisah

Mekanisme pembuatan biodiesel nyamplung terdiri dari penyaringan, menyiapkan sodium metoksit, pemanasan dan pencampuran serta pengendapan dan pemisahan. Minyak nyamplung yang masih kotor perlu disaring terlebih dahulu agar bersih dari kotoran. Kotoran biasanya berupa serpihan nyamplung hasil pemarutan yang ikut masuk ke dalam minyak nyamplung. Penyaringan yang dilakukan di sini menggunakan alat yang cukup sederhana yaitu kain yang rapat dan bersih.

Pembuatan sodium metoksit dilakukan dengan menyiapkan methanol dengan menggunakan gelas ukur yang selanjutnya dituang ke dalam labu takar yang sudah ada $\mathrm{NaOH}$. Setelah $\mathrm{NaOH}$ dan methanol dicampur kemudian dikocok sampai bercampur merata. Seiring dengan pembuatan sodium metoksit, minyak nyamplung dituang ke dalam bakker glass dan kemudian ditaruh di atas stirer untuk proses pemanasan hingga mencapai suhu $50^{\circ} \mathrm{C}$. Pemanasan tersebut kira-kira selama 5-10 menit tergantung dari penyetelan pemanasnya. Setelah suhu tersebut tercapai maka larutan sodium metoksid dituangkan ke dalam minyak nyamplung sambil diaduk sampai kedua larutan tersebut bercampur secara homogen. Pemanasan dan pengadukan secara merata dilakukan pada suhu $\pm 50^{\circ} \mathrm{C}\left(45-55^{\circ} \mathrm{C}\right)$ selama satu jam (Darmanto, 2010; Darmanto, 2006; Pelly, 2005). Setelah proses pemanasan dan pencampuran selesai kemudian campuran tersebut dimasukkan ke dalam corong pemisah. Di dalam corong pemisah, campuran tersebut didiamkan selama 24 jam, lebih 
lama lebih baik. Setelah terjadi endapan kemudian proses pemisahan dimulai yaitu dengan mengambil endapannya terlebih dahulu, di mana cairan yang di atas merupakan minyak biodisel.

\section{HASIL DAN PEMBAHASAN}

Biodiesel nyamplung secara prinsip diperoleh dari reaksi transesterifikasi. Reaksi transesterifikasi merupakan rekasi yang melibatkan methanol dan katalis asam dan atau basa. Pembuatan biodiesel nyamplung dalam penelitian ini dengan menggunakan katalis $\mathrm{NaOH}$. Pembuatan biodiesel nyamplung dengan beberapa komposisi memberikan hasil atau konversi minyak nyamplung ke biodiesel nyamplung yang berbeda. Kondisi perlakuan selama pembuatan biodiesel diatur sama yakni temperatur $50^{\circ} \mathrm{C}-55^{\circ} \mathrm{C}$ dan waktu total 75 menit. Total waktu pembuatan biodiesel terbagi dalam 2 (dua) tahapan proses meliputi 15 menit pemanasan awal dan 60 menit proses reaksi transesterifikasi.
Pembuatan biodiesel nyamplung dengan komposisi 450 minyak nyamplung, 50 methanol dan 2 gram $\mathrm{NaOH}\left(\mathrm{B}_{(450,50,2)}\right)$ memberikan hasil atau konversi minyak nyamplung ke biodiesel nyamplung relatif tinggi. Komposisi $\mathrm{B}_{(450,50,2)}$ menghasilkan konversi biodiesel nyamplung mencapai 95\%. Ukuran prosentase ini didasarkan pada volume metylester yang dihasilkan terhadap volume total (volume campuran). Volume total merupakan penjumlahan volume minyak nyamplung dan volume methanol. Dan pembuatan biodiesel nyamplung diatur bahwa penjumlahan volume minyak nyamplung dan volume methanol sebesar $500 \mathrm{ml}$. Pengamatan visual lebih lanjut terhadap biodiesel dengan komposisi $\mathrm{B}_{(450,50,2)}$ menunjukkan pembentukan endapan lilin (cristal wax) lebih tinggi dari pada $\mathrm{B}_{(400,100,2)}$. Pembentukan lapisan lilin juga terjadi pada biodiesel dengan komposisi $\mathrm{B}_{(400,100,2)}$. Lapisan lilin pada biodiesel ini terbentuk pada malam hari dan akan menghilang pada saat siang sampai sore hari.

Tabel.1.Hasil pengujian karakteristik bahan bakar biodiesel nyamplung

No.

Jenis Pemeriksaan
Hasil pemeriksaan biodisel

Metode Pemeriksaan

\begin{tabular}{llccc} 
& & \multicolumn{2}{c}{ B 10 } & Bom calorimetry \\
\cline { 3 - 4 } 1. & Calorific value, kal/gr & 9089,2 & - & ASTM D 93-00 \\
2. & Flash Point PMcc, ${ }^{\circ} \mathrm{C}$ & 54.5 & 40.5 & ASTM D 445-07 \\
\hline
\end{tabular}

Pembuatan biodiesel nyamplung dengan komposisi 400 minyak nyamplung, 100 methanol dan 2 gram $\mathrm{NaOH}\left(\mathrm{B}_{(400,100,2)}\right)$ memberikan hasil atau konversi minyak nyamplung ke biodiesel nyamplung relatif lebih rendah dan stabil. Kestabilan biodiesel didasarkan pada kondisi fisik bahan bakar yang relatif konstan pada berbagai kondisi cuaca. Komposisi $\mathrm{B}_{(400,100,2)}$ memberikan kondisi relatif stabil dibanding dengan biodiesel nyamplung dengan komposisi lain. Komposisi $\mathrm{B}_{(400,100,2)}$ juga menghasilkan konversi biodiesel nyamplung cukup tinggi yakni mencapai 86\%. Dan untuk langkah kajian dan analisa lebih lanjut, biodiesel nyamplung dengan komposisi $\mathrm{B}_{(400,100,2)}$ dibuat lebih banyak untuk uji properties dan unjuk kerja di mesin diesel.

Kajian literatur untuk sifat fisik dan kimia (properties) menunjukkan bahwa solar mempunyai nilai kalor $10.891 \mathrm{kal} /$ gram, flash point $48^{\circ} \mathrm{C}$ dan kekentalan 3,694 $\mathrm{mm}^{2} / \mathrm{s}$. Kekentalan bahan bakar biodiesel nyamplung cenderung lebih kental. Biodiesel nyamplung murni mempunyai kekentalan $5,317 \mathrm{~mm}^{2} / \mathrm{s}$. Pencampuran bahan bakar biodiesel nyamplung dengan solar pada berbagai komposisi menghasilkan penurunan nilai kekentalan terhadap kekentalan bahan bakar biodiesel. Bahan bakar dengan komposisi B10 menghasilkan kekentalan $4,151 \mathrm{~mm}^{2} / \mathrm{s}$. Selanjutnya titik nyala (flash point) bahan bakar biodiesel nyamplung cenderung lebih tinggi dari pada solar. Biodiesel nyamplung murni mempunyai titik nyala (flash point) $54,5^{\circ} \mathrm{C}$. Pencampuran bahan bakar biodiesel nyamplung dengan solar pada komposisi menghasilkan penurunan nilai titik flash point terhadap flash point bahan bakar biodiesel nyamplung murni. Bahan bakar dengan komposisi B10 menghasilkan fash point $40,5^{\circ} \mathrm{C}$. Nilai kalor (calorific value) bahan bakar biodiesel nyamplung cenderung lebih rendah sedikit dari pada solar. Kajian literatur solar menunjukkan nilai kalor 10.891 kalori per gram. Sedangkan pengujian bahan bakar biodiesel nyamplung murni menghasilkan 9089,2 kalori per gram. Dengan mengkaji bahwa kekentalan dan titik nyala biodiesel nyamplung yang sedikit lebih tinggi dari solar dan nilai kalor yang sedikit lebih rendah dari pada solar maka biodiesel nyamplung mempunyai potensi besar untuk diaplikasikan sebagai bahan bakar alternatif mesin diesel (Darmanto at. al., 2009).

\section{DAFTAR PUSTAKA}

1. Darmanto, S, 2010, Analisa Karakteristik Biodisel Kapuk Randu sebagai Bahan Bakar Biodiesel, TRAKSI, Vol. 10, No.2 , 2010, ISSN : 1693 - 3451

2. Darmanto, S, Handayani, S, Sediono, S dan Susuanti, 2009, Produksi Biodiesel Kapuk Randu dan Uji Unjuk Kerja di Mesin 
Diesel, Jurnal Litbang Provinsi Jawa Tengah, Vol. 7 No1 Juni 2009, ISSN 1412-9833

3. Darmanto, S,2006, Analisa Biodisel Kelapa Sebagai Bahan Bakar Alternatif Minyak Diesel, TRAKSI Vol. 4, No. 2, 2006 ISSN : 1693 - 3451

4.Humas@litbang.deptan.go.id, 2005, Prospek dan Arah Pengembangan Agrobisnis: Kelapa, Badan Penelitian dan Pengembangan Pertanian (Indonesian Agency for Agricultural Research and Development), Jl. Ragunan 29 Pasarminggu Jakarta Selatan 12540, Indonesia

5. Prakoso, T., 2005, Perguruan Tinggi Minati Biodiesel, Info Penelitian, Cakrawala, Kamis 21 Juli 2005

6. Pelly, M., 2005, Mike Pelly's biodiesel method. 